\title{
Molecular Cloning, Characterization, and mRNA Expression of Hemocyanin Subunit in Oriental River Prawn Macrobrachium nipponense
}

\author{
Youqin Kong, ${ }^{1,2}$ Liqiao Chen, ${ }^{1}$ Zhili Ding, ${ }^{1,2}$ Jianguang Qin, ${ }^{3}$ \\ Shengming Sun, ${ }^{1}$ Ligai Wang, ${ }^{1}$ and Jinyun $\mathrm{Ye}^{2}$ \\ ${ }^{1}$ School of Life Sciences, East China Normal University, Shanghai 200062, China \\ ${ }^{2}$ School of Life Sciences, Huzhou University, Huzhou, Zhejiang 313000, China \\ ${ }^{3}$ School of Biological Sciences, Flinders University, Adelaide, SA 5001, Australia
}

Correspondence should be addressed to Liqiao Chen; lqchen@bio.ecnu.edu.cn

Received 6 May 2016; Accepted 14 June 2016

Academic Editor: Wenwei Xiong

Copyright (c) 2016 Youqin Kong et al. This is an open access article distributed under the Creative Commons Attribution License, which permits unrestricted use, distribution, and reproduction in any medium, provided the original work is properly cited.

Hemocyanin is a copper-containing protein with immune function against disease. In this study, a hemocyanin subunit named MnHc-1 was cloned from Macrobrachium nipponense. The full-length cDNA of MnHc-1 was 2,163 bp with a 2,028-bp open reading frame (ORF) encoding a polypeptide of 675 amino acids. The MnHc-1 mRNA was expressed in the hepatopancreas, gill, hemocytes, intestine, ovary, and stomach, with the highest level in the hepatopancreas. In the infection trial, the MnHc-1 mRNA transcripts in the hemocytes were significantly downregulated at $3 \mathrm{~h}$ after injection of Aeromonas hydrophila and then upregulated at $6 \mathrm{~h}$ and $12 \mathrm{~h}$, followed by a gradual recovery from 24 to $48 \mathrm{~h}$. The MnHc-1 transcriptional expression in the hepatopancreas was measured after M. nipponense were fed seven diets with 2.8, 12.2, 20.9, 29.8, 43.1, 78.9, and $157.1 \mathrm{mg} \mathrm{Cu} \mathrm{kg}^{-1}$ for 8 weeks, respectively. The level of MnHc-1 mRNA was significantly higher in the prawns fed $43.1-157.1 \mathrm{mg} \mathrm{Cu} \mathrm{kg}^{-1}$ diet than in that fed $2.8-29.8 \mathrm{mg} \mathrm{Cu} \mathrm{kg}^{-1}$ diet. This study indicated that the MnHc-1 expression can be affected by dietary copper and the hemocyanin may potentially participate in the antibacterial defense of M. nipponense.

\section{Introduction}

Crustaceans like other invertebrates only have innate immunity, including many immune molecules to eliminate exogenous pathogens [1]. To date, many studies have verified that hemocyanin is an important nonspecific innate immune defense molecule and can provide an effective immune defense in arthropods [2-8]. Hemocyanin is a coppercontaining multifunctional protein in mollusks and arthropods [9]. Its primary function is to transport and store oxygen and also to participate in osmoregulation, molt cycle, exoskeleton formation, and melanin synthesis [10-12]. So far, studies on the immunologic function in crustacean are mainly focused on the hemocyanin itself or its degraded peptides, which have hemolytic activity, agglutination property, and antiviral function $[2,4,5,7,13]$. Hemocyanin genes have been cloned and characterized in certain crustacean species such as Litopenaeus vannamei [14], Eriocheir sinensis [15], Cherax quadricarinatus [16], Homarus americanus [17], and Caridina multidentata and Atyopsis moluccensis [18].

Copper is a central component of hemocyanin and a cofactor of many other enzymes, like superoxide dismutase, cytochrome oxidase, and lysyl oxidase $[19,20]$. The dietary copper level can affect crustacean immune responses in Penaeus monodon [21] and E. sinensis [22]. It was found that the expression of hemocyanin mRNA in E. sinensis was affected by dietary copper level [15]. Investigation of the functional relationship between dietary copper and hemocyanin mRNA expressions can provide better understanding on crustacean innate immunity and offer insight into disease control through dietary management in shrimp farming. We hypothesize that copper as a major component of hemocyanin can impact prawn innate immunity through dietary copper manipulation. 
Oriental river prawn (Macrobrachium nipponense) is an important aquaculture species in China and other Southeast Asian countries [23]. Various diseases have been found in the M. nipponense farming population due to intensive culture and environmental pollution [24]. For example, the bacterial disease induced by Aeromonas hydrophila is one of the major diseases which can cause $30 \%$ death of prawn, sometimes as high as $70 \%$ [25]. As a result, the investigation on the $M$. nipponense innate immune mechanism against $A$. hydrophila has become a key issue of health management in crustacean farming. The hemocyanin subunit is a functional group for crustacean immunity, and a hemocyanin subunit has been cloned and characterized in the freshwater prawn M. nipponense [26]. In this study, we discovered another hemocyanin subunit in $M$. nipponense (MnHc-1). To understand the role of MnHc-1 in M. nipponense immunization, (1) the full-length cDNAs of MnHc-1 was cloned, (2) the distribution of MnHc1 in different tissues was examined, (3) the mRNA expression of $\mathrm{MnHc}-1$ in immune defense after prawn challenge with A. hydrophila was examined, and (4) the relative expression level of MnHc-1 in the hepatopancreas of M. nipponense fed different levels of copper was quantified.

\section{Materials and Methods}

2.1. Sample Collection and Infection Test. All adult oriental river prawns (M. nipponense) were obtained from a local farm in Shanghai. The hepatopancreas, muscle, gill, ovary, intestine, heart, and stomach were collected from healthy prawn, flash-frozen in liquid nitrogen, and stored at $-80^{\circ} \mathrm{C}$ until RNA extraction. A total of $1 \mathrm{~mL}$ hemolymph was collected from the ventral sinus using a sterile syringe and diluted using half volume of anticoagulant solution [27], then centrifuged at $8000 \times \mathrm{g}$ for $10 \mathrm{~min}$ at $4^{\circ} \mathrm{C}$ to collect the hemocyte, and stored at $-80^{\circ} \mathrm{C}$ immediately until RNA extraction.

Prior to the challenge experiment, the adult prawns were acclimatized in the laboratory for 2 weeks. A total of 300 healthy prawns were randomly divided into two groups with five replicates. According to the preliminary experiment, the prawn in the bacterial challenge trial was injected with $100 \mu \mathrm{L}$ A. hydrophila in saline suspension $\left(1 \times 10^{7} \mathrm{CFU} / \mathrm{mL}\right)$ obtained from Shanghai Ocean University, while each prawn in the control group received the same volume of saline injection. After injection, prawns were put back to the rearing tanks, and hemocyte samples were collected at $0,3,6,12,24$, and $48 \mathrm{~h}$ after injection, centrifuged, and stored at $-80^{\circ} \mathrm{C}$ for RNA extraction.

2.2. Experimental Diets and Farming. The juvenile M. nipponense were obtained from the same farm as the adults and acclimated for two weeks in the laboratory conditions prior to the feeding trial. The basal diet was supplemented with copper sulphate (Analytical Reagent, Shanghai Chemical Co., Shanghai, China) at $0,10,20,30,40,80$, and $160 \mathrm{mg} \mathrm{Cu} \mathrm{kg}^{-1}$ diet, respectively. Procedure of diet preparation was similar to that described by $\mathrm{Li}$ et al. [28], and all other required nutrients for $M$. nipponense were included. The actual copper concentrations in the feeds were analyzed to be 2.8, 12.2, 20.9, $29.8,43.1,78.9$, and $157.1 \mathrm{mg} \mathrm{kg}^{-1}$, respectively, by the flame
TABLE 1: Ingredients and compositions of experimental diets (\%).

\begin{tabular}{lc}
\hline Ingredient $^{2}$ & Percentage of dry weight \\
\hline Casein $^{\mathrm{a}}$ & 30 \\
Fish meal $^{\mathrm{b}}$ & 20 \\
Corn starch $^{\mathrm{a}}$ & 26 \\
Fish oil $^{\mathrm{c}}$ & 4 \\
Soybean oil $^{\mathrm{d}}$ & 2 \\
Vitamin mix $^{\mathrm{e}}$ & 2 \\
Cu-free mineral mix $^{\mathrm{f}}$ & 3 \\
Attractant $^{\mathrm{g}}$ & 3 \\
Cholesterol $^{\mathrm{h}}$ & 0.5 \\
Choline chloride $^{\mathrm{h}}$ & 0.5 \\
Lecithin $^{\mathrm{h}}$ & 0.5 \\
Cellulose $^{\mathrm{h}}$ & 6.5 \\
Sodium carboxymethylcellulose $^{\mathrm{h}}$ & 2 \\
Proximate composition $^{\text {Crude protein }}$ & \\
Crude lipid $_{\text {Crude ash }}$ & 40.6 \\
\hline
\end{tabular}

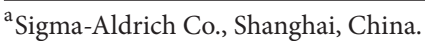

${ }^{\mathrm{b}}$ Tecnologica De Alimentos USA.

${ }^{c}$ Xiamen Xinsha Pharmaceutical Co. Ltd., Xiamen, China.

${ }^{\mathrm{d}}$ National Golden Dragon Fish Co. Ltd., Shanghai, China.

${ }^{\mathrm{e}}$ Vitamin mixture (mg/100 g mixture): vitamin A $420000 \mathrm{IU}$; vitamin C $6000 \mathrm{mg} ; \alpha$-tocopherol acetate $2000 \mathrm{mg}$; vitamin D3 $120000 \mathrm{IU}$; vitamin K 1000 mg; vitamin B1 1000 mg; vitamin B2 1000 mg; vitamin B6 1600 mg; vitamin B12 2 mg; niacin $5000 \mathrm{mg}$; folic acid $400 \mathrm{mg}$; inositol $6000 \mathrm{mg}$; biotin $10 \mathrm{mg}$; and calcium pantothenic $3500 \mathrm{mg}$, Hangzhou Minsheng Bio-Tech Co., Ltd., China.

${ }^{\mathrm{f}}$ Composition of mineral mixture (g/kg diet): $\mathrm{KCl} 0.84, \mathrm{MgSO}_{4} \cdot 7 \mathrm{H}_{2} \mathrm{O}$ 3, $\mathrm{NaH}_{2} \mathrm{PO}_{4}$ 6.45, $\mathrm{KH}_{2} \mathrm{PO}_{4} 3, \mathrm{Ca}\left(\mathrm{H}_{2} \mathrm{PO}_{4}\right)_{2} \cdot \mathrm{H}_{2} \mathrm{O}$ 7.95, $\mathrm{CaCO}_{3}$ 3.15, $\mathrm{C}_{6} \mathrm{H}_{10} \mathrm{CaO}_{6} \cdot 5 \mathrm{H}_{2} \mathrm{O} \quad 4.95, \mathrm{FeC}_{6} \mathrm{H}_{5} \mathrm{O}_{7} \cdot 5 \mathrm{H}_{2} \mathrm{O} \quad 0.36, \mathrm{ZnSO}_{4} \cdot 7 \mathrm{H}_{2} \mathrm{O} \quad 0.1428$, $\mathrm{MnSO}_{4} \cdot \mathrm{H}_{2} \mathrm{O} 0.0321, \mathrm{Na}_{2} \mathrm{SeO}_{3} 0.0009, \mathrm{AlCl}_{3} \cdot 6 \mathrm{H}_{2} \mathrm{O} 0.0045, \mathrm{CoCl}_{2} \cdot 6 \mathrm{H}_{2} \mathrm{O}$ 0.042 , and $\mathrm{KI} 0.0069$.

${ }^{\mathrm{g}}$ Alanine $0.6 \%$, glycine $0.6 \%$, glutamic acid $0.6 \%$, and betaine $1.2 \%$.

${ }^{\mathrm{h}}$ China National Medicine Corporation Co., Ltd., Beijing, China.

atomic absorption photometry [29]. The compositions of the experimental diet were showed in Table 1.

Prawn juveniles $(0.101 \pm 0.001 \mathrm{~g})$ were randomly placed in 21 of $300-\mathrm{L}$ tanks with 30 prawns per tank in triplicate. Prawns were fed to apparent satiation twice daily (8:00 and 17:00 h) for 56 days. To maintain water quality, one-third of the tank water was exchanged daily. During the feeding period, water temperature was $27-30^{\circ} \mathrm{C}$, dissolved oxygen $>6.5 \mathrm{mg} \mathrm{L}^{-1}$, and total ammonia nitrogen $<0.1 \mathrm{mg} \mathrm{L}^{-1}$. The $\mathrm{Cu}$ concentration in rearing water was $1.4-1.7 \mu \mathrm{g} \mathrm{Cu} \mathrm{L}^{-1}$. At the end of the feeding trial, all prawns were counted and gained survival rate (Survival rate $=100 \times$ (final prawn number)/(initial prawn number)). Prawns were fasted for $24 \mathrm{~h}$ before the hepatopancreas was collected. These samples were stored at $-80^{\circ} \mathrm{C}$ until RNA extraction.

2.3. RNA Extraction and Reverse Transcription. Total RNA was isolated using RNA extraction kit (Aidlab Biotech, Beijing, China) following manufacture protocol. In reverse transcription reaction, $3 \mu \mathrm{g}$ of total RNA was used for synthesis of first-strand cDNA by the PrimeScript ${ }^{\mathrm{TM}}$ RT-PCR 
TABle 2: Primers used in our study.

\begin{tabular}{ll}
\hline Name & Sequence $\left(5^{\prime}-3^{\prime}\right)$ \\
\hline MnHc-s1 & GTCGACTCTACTCCTCTTGG \\
MnHc-a1 & TCGGTTATCCTTCAGCTC \\
MnHc-s2 & TTCTGCTGATGCCTCCAA \\
MnHc-a2 & TTCTTCACGGTGCCTGTC \\
MnHc-5' GSP & GGCGGTGAACAGCTTCTCCATTATC \\
MnHc-3' GSP & GCATGATGTGAACTTCCTCCTGTGG \\
$5^{\prime}$-RACE CDS primer A & $(\text { T })_{25}$ V N $(\mathrm{N}=$ A, C, or or V $=$ A, or C) \\
$3^{\prime}$-RACE CDS primer A & AAGCAGTGGTATCAACGCAGAGTAC(T) $)_{30}$ V N \\
UPM & CTAATACGACTCACTATAGGGCAAGCAGTGGTATCAACGCAGAGT \\
$\beta$-Actin-s & CTAATACGACTCACTATAGGGC \\
$\beta$-Actin-a & GTGCCCATCTACGAGGGTTA \\
\hline
\end{tabular}

Kit (TaKaRa, Dalian, China). Acquired cDNA was stored at $-20^{\circ} \mathrm{C}$ for subsequent quantitative real-time PCR (qRTPCR).

2.4. $3^{\prime}$-RACE and $5^{\prime}$-RACE Amplification of MnHc-1 Gene, Cloning, and Sequencing. To get the full length of MnHc1 cDNA sequence, SMART ${ }^{\mathrm{TM}}$ RACE cDNA Amplification Kit (Clontech, USA) was used to conduct the $3^{\prime}$-RACE and $5^{\prime}$-RACE. Gene-specific primers of MnHc-1 were designed based on the known fragments initially identified from the EST cDNA library of $M$. nipponense [30]. The total RNA of the mixed hepatopancreas was used as a template. PCR was performed in a Bio-Rad thermal cycler. Reaction volume was $50 \mu \mathrm{L}$ containing $5.0 \mu \mathrm{L} 10 \mathrm{x}$ Ex Taq Buffer $\left(\mathrm{Mg}^{2+}\right.$ Plus), $5.0 \mu \mathrm{L}$ 10x UPM, $4.0 \mu \mathrm{L}$ cDNA template, $4.0 \mu \mathrm{L}$ dNTPs mix $(2.5 \mathrm{mM}$ each), $1.0 \mu \mathrm{L}$ GSP $(10 \mu \mathrm{M}), 0.26 \mu \mathrm{L}$ Ex Taq HS (TaKaRa, Dalian, China), and $30.74 \mu \mathrm{L}$ of sterile deionized water. The PCR conditions were set as follows: 5 cycles of $94^{\circ} \mathrm{C}$ for $30 \mathrm{~s}$ and $72^{\circ} \mathrm{C}$ for $3 \mathrm{~min}$, then 5 cycles of $94^{\circ} \mathrm{C}$ for $30 \mathrm{~s}$ and $70^{\circ} \mathrm{C}$ for $30 \mathrm{~s}$, and $25 \mathrm{cycles}$ of $94^{\circ} \mathrm{C}$ for $30 \mathrm{~s}, 68^{\circ} \mathrm{C}$ for $30 \mathrm{~s}$, and $72^{\circ} \mathrm{C}$ for $3 \mathrm{~min}$. All used primers were summarized in Table 2. Primers of MnHc-s1 and MnHc-al were used to confirm the MnHc1 fragment from the EST cDNA library. $5^{\prime}$-CDS primer A (as the RT primer), gene-specific primer of $\mathrm{MnHc}-5^{\prime} \mathrm{GSP}$, and the UPM (universal primer A mix) were used for the $5^{\prime}$-RACE. $3^{\prime}$-CDS primer A (as the RT primer), gene-specific primer of MnHc- $3^{\prime}$ GSP, and the UPM were used for the $3^{\prime}$-RACE.

The PCR products were purified by the UNIQ-10 Gel Extraction Kit (Sangon, Shanghai, China) and cloned into the pUCm-T vector (Sangon, Shanghai, China). The transformed bacteria were identified, confirmed by blue/white screening, and validated by PCR. More than two recombinant plasmids were sequenced using BigDye Terminator v3.1 Cycle Sequencing Kit operating on an Automatic DNA Sequencer (ABI 3730xl DNA Analyzer).

2.5. Sequence Analysis. The online ORF finder program (http://www.ncbi.nlm.nih.gov/gorf/) was used to predict the gene's putative open reading frame. The BLAST algorithm at the National Center for Biotechnology Information (http://www.ncbi.nlm.nih.gov/BLAST/) was applied to search for sequence homology. SMART (Simple Modular Architecture Research Tool, http://smart.embl-heidelberg .de/) was used to predict conserved motifs. Signal sequence was carried out using SignalP 4.1 program (http://www.cbs .dtu.dk/services/SignalP/). The deduced amino acid sequence of MnHc-1 from $M$. nipponense and other invertebrate hemocyanin sequences acquired from NCBI database were aligned by software ClustalX. A neighbor-joining (NJ) phylogenetic relationship was established based on amino acid sequences of the hemocyanin using the MEGA 5.1 program (http://www.megasoftware.net/).

2.6. Analysis of the MnHc-1 Expression in Tissues. The mRNA expression of MnHc-1 in the hepatopancreas, muscle, gill, ovary, intestine, heart, and stomach was detected by qRTPCR with $\beta$-actin as internal control. The synthesis of the first-strand cDNA was the same as that described above. Gene-specific primers of MnHc-s2, MnHc-a2, $\beta$-actin-s, and $\beta$-actin-a were used in qRT-PCR (Table 2). The qRT-PCR liquid compositions and conditions were according to the manufacturer instructions of SYBR Premix Ex Taq (TaKaRa, Dalian, China). The qRT-PCR was conducted on the CFX96 ${ }^{\mathrm{TM}}$ Real-Time System (Bio-Rad, USA) according to the manufacturer's protocols. During the detection, each sample was run in triplicate. The melt curve of the amplification products was analyzed to ensure that only one PCR product was amplified and detected at the end of each PCR. Expression level of MnHc-1 was measured by $2^{-\Delta \Delta \mathrm{Ct}}$ method [31].

2.7. Analysis of the MnHc-1 Expression after A. hydrophila Challenge. The mRNA expression of MnHc-1 in the hemocytes of $M$. nipponense injected with $A$. hydrophila or saline water was, respectively, detected at $0,3,6,12,24$, and $48 \mathrm{~h}$ after injection by a quantitative real-time RT-PCR.

2.8. Analysis of the MnHc-1 Expression after the Feeding Treatment at Different Dietary Copper Levels. At the feeding experiment, mRNA expression of MnHc-1 in hepatopancreas of $M$. nipponense from the feeding treatment at seven copper levels was analyzed by qRT-PCR. 
2.9. Statistical Analysis. All the data are expressed as means \pm SD. SPSS software (version 16.0) was used for statistical analysis. The results of relative mRNA expression in challenge test were analyzed by $t$-test, while other results were subjected to one-way ANOVA and post hoc Duncan multiple range tests. Differences were regarded as significant at $P<0.05$.

\section{Results}

3.1. Sequence Analysis of $\mathrm{MnHc}-1$. The full length of MnHc-1 cDNA from the $M$. nipponense was 2,163 bp (GenBank accession number JX456149.1), containing a $20 \mathrm{bp} 5^{\prime}$-untranslated region, a $115 \mathrm{bp} 3^{\prime}$-untranslated region with poly $\mathrm{A}$ tail, and a 2,028 bp open reading frame (ORF) (Figure 1). The ORF encoded a polypeptide of 675 amino acids with a calculated molecular weight of $78.060 \mathrm{kDa}$ and an isoelectric point of 5.45. A putative signal peptide of 21 amino acids was found in the N-terminus by using SignalP 4.1 program [32]. SMART program predicted that the MnHc-1 belongs to the hemocyanin family, including $\mathrm{N}$ terminal domain (Ser24Val150), typical copper-containing domain (Pro154-Glu411), and $\mathrm{C}$ terminal domain (Pro417-His667 amino acid). Six histidine residues (H212, H216, H242, H362, H366, and H402) of copper-binding sites were identified [17].

3.2. Homology and Phylogenetic Analysis of MnHc-1. Homology analysis with BLAST algorithm showed that MnHc-1 amino acid sequences had 75\%,73\%, 70\%, and 68\% similarity to that of the A. moluccensis gamma subunit, P. monodon, C. quadricarinatus, and E. sinensis, respectively. The MnHc-1 exhibited $64 \%$ identity with another subunit of hemocyanin in $M$. nipponense (MnHc-2, GenBank accession number JF683437.1). A phylogenetic tree was constructed with the 24 full-length hemocyanin sequences from arthropod based on the neighbor-joining method (Figure 2). The result of phylogenetic analysis revealed that $\mathrm{MnHc}-1$ was more closely related to the hemocyanin gamma subunit 1 of freshwater shrimps A. moluccensis and C. multidentata.

3.3. Analysis of $\mathrm{MnHc}-1 \mathrm{mRNA}$ Expressions in Tissues. The mRNA transcripts of MnHc-1 were analyzed in the tissues of hepatopancreas, gill, muscle, hemocytes, intestine, ovary, and stomach. In prawn, the highest expression was found in hepatopancreas $(P<0.05)$; the expression value is 20.32 , which is 20 times higher or more compared with other tissues. The value is as low as 0 so that the gene is not expressed in muscle (Figure 3). It looks to us that its expression is tissuespecific.

3.4. Analysis of MnHc-1 mRNA Expression after Challenge with A. hydrophila. Figure 4 exhibits the expression profile of MnHc-1 in the hemocytes challenged by A. hydrophila from 0 to $48 \mathrm{~h}$. The expression of MnHc-1 showed a distinct timedependent pattern. The mRNA expression level significantly dropped at $3 \mathrm{~h}$ after injection $(0.6$ times $)(P<0.05)$ and then started to significantly increase and reached the peak in $12 \mathrm{~h}$ (6.2 times) $(P<0.05)$, followed by a recovery to the initial level in $24 \mathrm{~h}$ and $48 \mathrm{~h}$.
3.5. Analysis of $\mathrm{MnHc}-1 \mathrm{mRNA}$ Expression in Response to Graded Levels of Dietary Copper. Survival rate (70-81\%) of prawns was not affected by the dietary copper levels. As shown in Figure 5, the response of MnHc-1 expression in the hepatopancreas was affected by the dietary copper level. With the dietary copper level increasing from 43.1 to $157.1 \mathrm{mg} \mathrm{Cu} \mathrm{kg}^{-1}$ diet, the level of MnHc-1 mRNA in hepatopancreas of prawns significantly increased (1.9-fold to 5.8fold $)(P<0.05)$ and was significantly higher compared to that fed $2.8-29.8 \mathrm{mg} \mathrm{Cu} \mathrm{kg}^{-1} \operatorname{diet}(P<0.05)$, but differences in 2.8-29.8 groups were not significant $(P>0.05)$.

\section{Discussion}

Hemocyanin is an extracellular, multisubunit protein in crustacean $[14,33]$. Those subunits differ considerably in their primary structures and are encoded by distinct genes [34]. In this study, we cloned and characterized the expression pattern of one hemocyanin subunit from M. nipponense (MnHc-1). MnHc-1 was a polypeptide of 675 amino acids with a 21amino acid putative signal peptide. The signal peptide ends Ala-X-Ala motif, which is a frequent accordance prior to the cleavage site of signal peptides, suggesting that a cleavage site is located at the 21-22 amino acids [32, 35]. Structurally, MnHc-1 has conservative copper-binding domains including six histidine residues ( $\mathrm{H} 212, \mathrm{H} 216, \mathrm{H} 242, \mathrm{H} 362, \mathrm{H} 366$, and H402) of the copper-binding sites; this domain agrees with other crustaceans $[4,14,15]$. Based on immunological methods, the crustacean hemocyanin subunits are classified into three distinct subunit types: alpha, beta, and gamma [9]. The phylogenetic analysis showed that $\mathrm{MnHc}-1$ and $\mathrm{MnHc}$ 2 belong to separate clade; MnHc-1 belongs to the gamma subunit which has evolved at a later time compared to alpha and beta subunits in freshwater shrimps [18].

The present study showed that the highest level of MnHc1 mRNA expression occurred in the hepatopancreas. The result is the same as the findings in other crustaceans, such as H. americanus [17], Fenneropenaeus chinensis [36], and E. sinensis [15], and consistent with the report that hemocyanin synthesis occurs mainly in the hepatopancreas [37]. MnHc1 expression was detected in all the examined tissues except for muscle, which is different from another subunit of hemocyanin in $M$. nipponense (MnHc-2) expressed in the muscle [26]. We also found that $\mathrm{MnHc}-1$ was expressed in ovary, whereas MnHc-2 was hardly expressed in ovary [26]. The discrepant expression patterns of these two subunits of hemocyanin may be owing to their functional specialization in different tissues.

Hemocyanin is an important multifunctional protein in mollusks and arthropods. Besides its role as an oxygen carrier, its immune functions including antibacterial activities, agglutination property, and PO activity have become hot topics of immunological research [2, 4, 5, 7]. Zhang et al. [38] found that the main protein directly bound to the Vibrio alginolyticus, Vibrio harveyi, A. hydrophila, and Staphylococcus aureus in L. vannamei serum was hemocyanin, suggesting that hemocyanin possesses antibacterial functions. The Cterminus of L. vannamei hemocyanin is possibly related to 


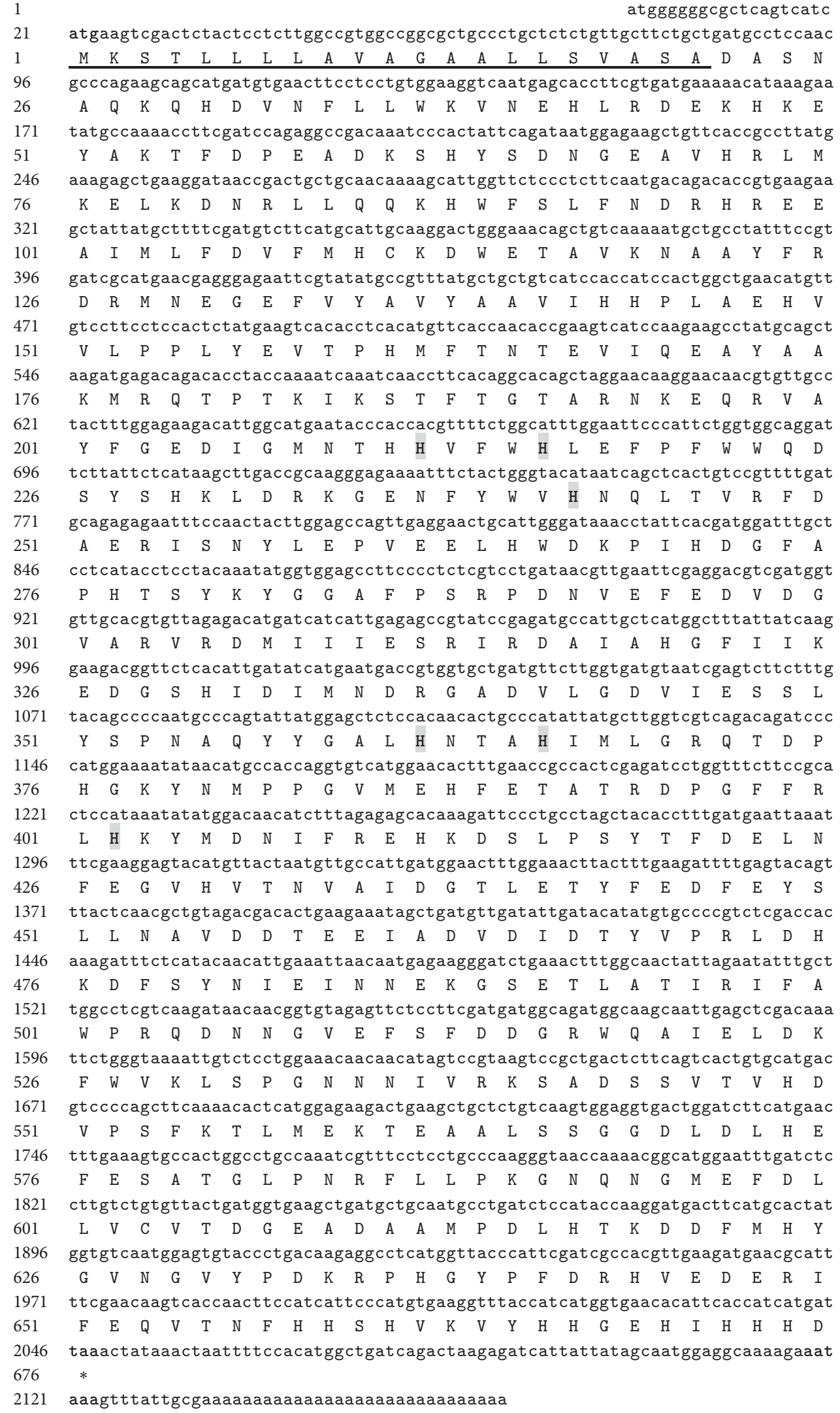

FIGURE 1: M. nipponense hemocyanin subunit $1 \mathrm{cDNA}$ and deduced amino acid sequences. Putative signal peptide sequences were underlined. The start codon (atg), stop codon (taa), and the polyadenylation signal sequence (aataaa) were marked in bold and the six histidine residues within the copper-binding sites were marked in bold and shadow background. 


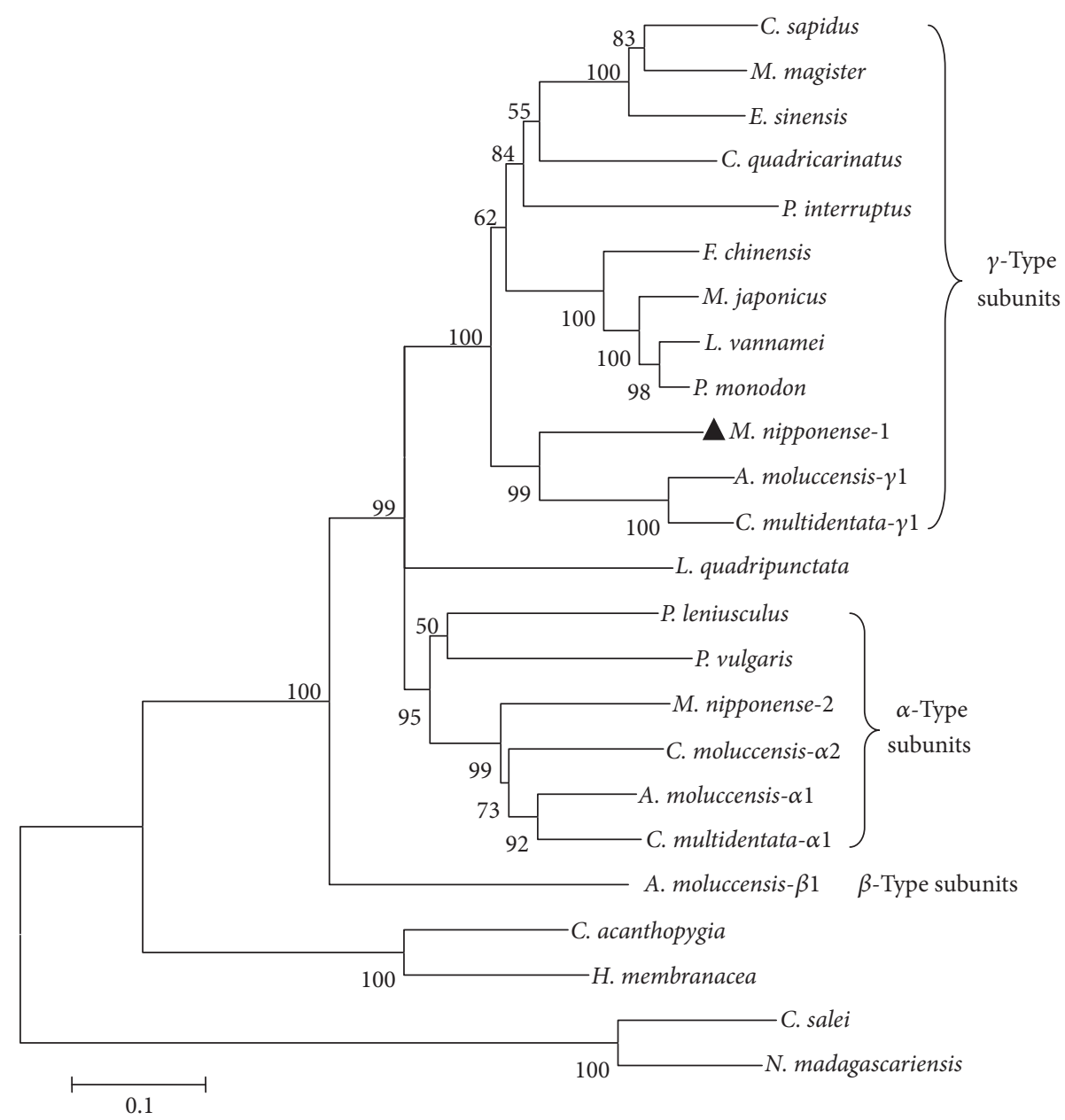

FIgURE 2: The phylogenetic tree based on the sequences of hemocyanin from different species. The amino acid sequences were derived from the GenBank as the following accession numbers: A. moluccensis- $\alpha 1$ (CCF55379.1); A. moluccensis- $\beta 1$ (CCF55382.1); A. moluccensis$\gamma 1$ (CCF55383.1); C. acanthopygia (CAR85694.1); C. multidentata- $\alpha 1$ (CCF55384.1); C. multidentata- $\alpha 2$ (CCF55385.1); C. multidentata$\gamma 1$ (CCF55387.1); C. quadricarinatus (AFP23115.1); C. salei (CAC44753.1); C. sapidus (AAF64305.1); E. sinensis (AEG64817.1); F. chinensis (ACM61982.1); H. membranacea (CAR85695.1); L. quadripunctata (ADE58571.1); L. vannamei (ADZ15149.1); M. japonicus (ABR14693.1); M. magister (AAW57893.1); M. nipponense-1 (AGA17871.1); M. nipponense-2 (AEC46861.1); N. madagascariensis (CAD68057.1); P. interruptus (AAB22190.1); P. leniusculus (AAO47336.1); P. monodon (AEB77775.1); and P. vulgaris (CAC69244.1).

the immunity in shrimp to different pathogens [39]. Gramnegative bacteria $A$. hydrophila are a common species of the Aeromonas genus in water and water habitants [40]. The infection of $A$. hydrophila in fish and prawn including $M$. nipponense has been one of the major diseases under farming conditions $[25,41]$. Sun et al. [15] showed that the hemocyanin gene expression of $E$. sinensis was significantly upregulated by A. hydrophila infection. In our study, temporal and spatial expressions of MnHc-1 in the hemocytes of prawn infected with $A$. hydrophila showed a clear time-dependent pattern. The level of MnHc-1 mRNA expression significantly decreased at $3 \mathrm{~h}$ after injection, then started to significantly increase after $6 \mathrm{~h}$ and $12 \mathrm{~h}$, and then reached the peak at $12 \mathrm{~h}$, implying that the hemocyanin is involved in the antibacterial defense of prawn. In another study, the level of MnHc-2 mRNA expression in prawn significantly increased over time and peaked at $3 \mathrm{~h}$ after the A. hydrophila challenge [26].
Clearly, these two hemocyanin subunits respond quite differently in defense against bacterial infection. Transcriptional upregulation in MnHc-1 was found after $6 \mathrm{~h}$ of A. hydrophila injection. Lei et al. [4] found a similar result in $P$. japonicus that $P j H c L$ transcriptional upregulation occurred after $4 \mathrm{~h}$ of injection of the active WSSV. It is possible that $P j H c L$ may be triggered by the fast expressed proteins in virus. It is also likely that MnHc-1 may be induced by fast expressed protein in bacteria, but the detailed defensing mechanism of hemocyanin against bacterial infection needs further study.

The expression of hemocyanin subunits varies with environmental or nutritional changes $[42,43]$. Copper is the metal in the center of a hemocyanin molecule [42]. In $E$. sinensis, expression of hemocyanin mRNA was affected by the level of dietary copper [15]. Our present study showed that the level of dietary copper affected the hemocyanin gene expression in prawn. The level of MnHc-1 mRNA 


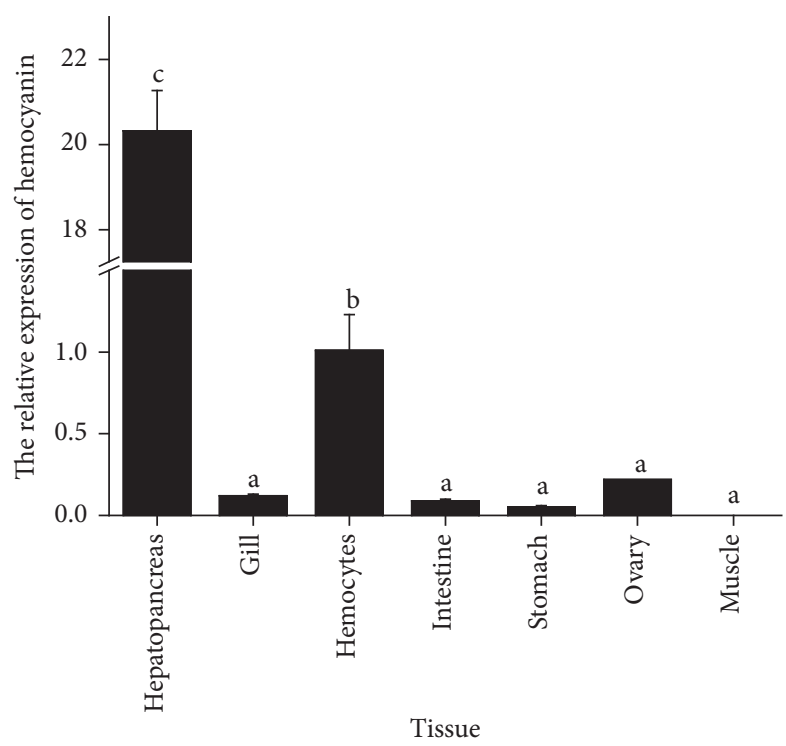

FIGURE 3: Quantitative real-time PCR analysis of hemocyanin expressions in various tissues of M. nipponense. The $\beta$-actin gene was used as the internal control. Different letters in each index indicated significant differences $(P<0.05)$.

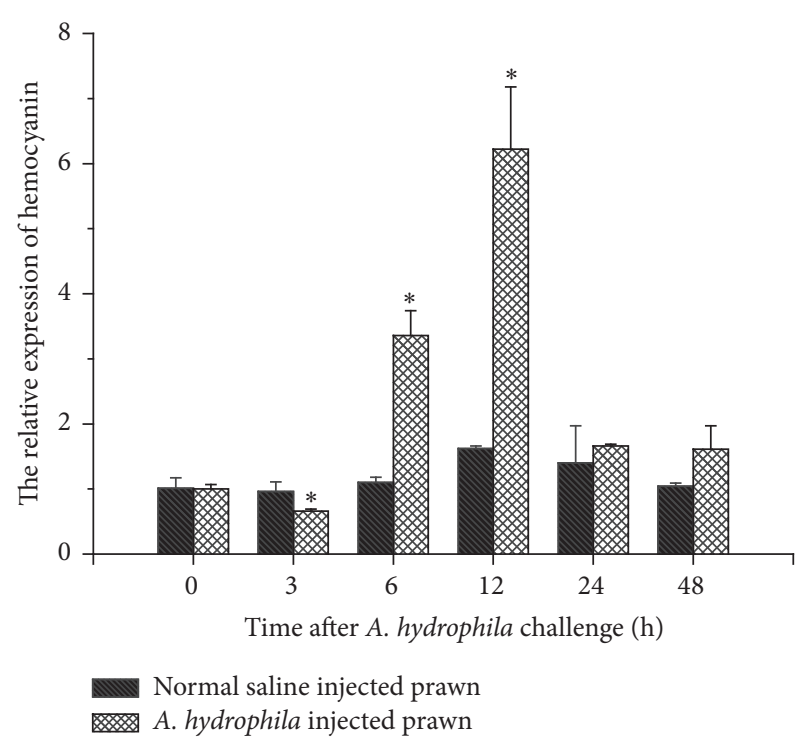

Figure 4: The hemocyanin gene expression in hemocytes of $M$. nipponense. The statistical test was performed by $t$-test after challenge with $A$. hydrophila compared to the control at the same time points $(0,3,6,12,24$, and $48 \mathrm{~h})$. The internal standard was $\beta$-actin gene. Asterisks indicate being significantly different $(P<0.05)$.

in hepatopancreas of the prawn fed $43.1-157.1 \mathrm{mg} \mathrm{Cu} \mathrm{kg}^{-1}$ diet was significantly higher compared to that fed 2.8$29.8 \mathrm{~m} \mathrm{Cu} \mathrm{kg}^{-1}$. The increase of dietary $\mathrm{Cu}$ concentration also increased the $\mathrm{Cu}$ content in hepatopancreas, especially in the $43.1-157.1 \mathrm{mg} \mathrm{Cu} \mathrm{kg}^{-1}$ groups. Hemocyanin synthesis mainly occurs in the hepatopancreas [37]. Therefore, we suggest that the high level of copper content in the hepatopancreas can trigger MnHc-1 mRNA expression, whereas

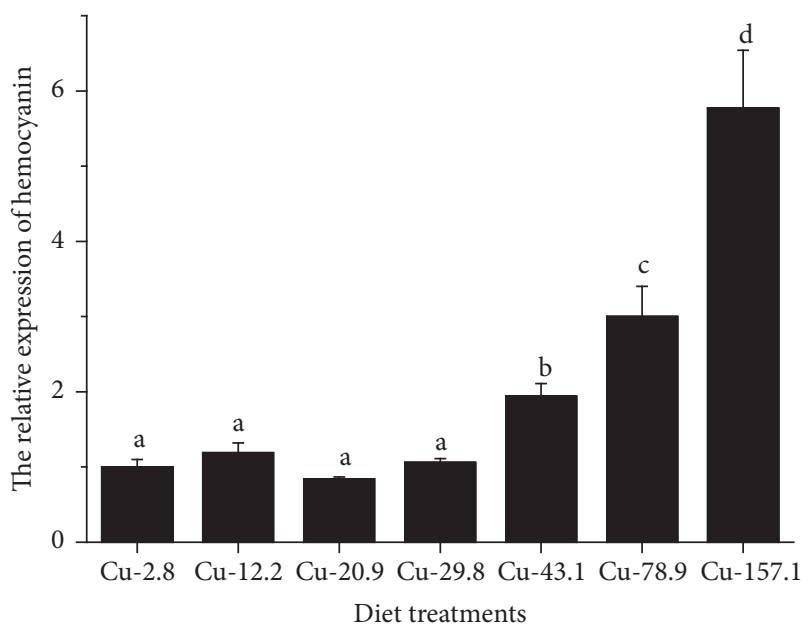

FIGURE 5: Relative hemocyanin mRNA levels in hepatopancreas of M. nipponense. M. nipponense was fed diet with different levels of copper for 8 weeks. Hemocyanin mRNA levels were evaluated by qRT-PCR and expressed relatively to the level of $\beta$-actin mRNA. Different letters in each index indicated significant differences $(P<$ 0.05).

the optimal level of dietary copper (20-40 $\mathrm{mg} \mathrm{kg}^{-1}$ diet) can increase hemocyanin mRNA expression in the hepatopancreas and hemocytes of crab [15]. These studies suggest that the effect of dietary copper level on hemocyanin mRNA expression is species-specific. It seems that the two subunits of hemocyanin may have structural functions in their own hemocyanin and show different response to the level of dietary copper. Hemocyanin is a copper-containing protein that mainly carries oxygen in crustaceans [9]. Dietary copper may be first used for hemocyanin synthesis as low dietary copper did not reduce the level of MnHc-1 mRNA.

In conclusion, we cloned the hemocyanin subunit gene (MnHc-1) from the hepatopancreas of M. nipponense. Our results suggest that MnHc-1 may play a critical role in antibacterial defense in prawn. Accumulation of high copper levels in hepatopancreas of prawn triggers $\mathrm{MnHc}-1$ gene expression. These results provide the foundation for further studies in biological function and regulation of hemocyanin in crustacean.

\section{Competing Interests}

The authors declare that they have no competing interests.

\section{Acknowledgments}

This research was supported by grants from the Special Fund for Agro-Scientific Research in the Public Interest (nos. 201003020 and 201203065), Shanghai Committee of Science and Technology, China (10JC1404100, 09ZR1409800), National "Twelfth Five-Year" Plan for Science \& Technology Support (2012BAD25B03), the National Basic Research Program (973 Program, no. 2009CB118702), National Natural Science Foundation of China (nos. 31172422, 31001098, and 31402308), and Shanghai Technology System for Chinese 
Mitten-Handed Crab Industry and partly by the E-Institute of Shanghai Municipal Education Commission (no. E03009) and Zhejiang Provincial Natural Science Foundation of China (nos. LQ14C190004 and LY16C190006).

\section{References}

[1] S. Iwanaga and L. L. Bok, "Recent advances in the innate immunity of invertebrate animals," Journal of Biochemistry and Molecular Biology, vol. 38, no. 2, pp. 128-150, 2005.

[2] H. Decker and E. Jaenicke, "Recent findings on phenoloxidase activity and antimicrobial activity of hemocyanins," Developmental and Comparative Immunology, vol. 28, no. 7-8, pp. 673687, 2004.

[3] H. Decker, M. Ryan, E. Jaenicke, and N. Terwilliger, "SDSinduced Phenoloxidase Activity of Hemocyanins from Limulus polyphemus, Eurypelma californicum, and Cancer magister," Journal of Biological Chemistry, vol. 276, no. 21, pp. 17796-17799, 2001.

[4] K. Y. Lei, F. Li, M. C. Zhang, H. Yang, T. Luo, and X. Xu, "Difference between hemocyanin subunits from shrimp Penaeus japonicus in anti-WSSV defense," Developmental and Comparative Immunology, vol. 32, no. 7, pp. 808-813, 2008.

[5] X. B. Zhang, C. H. Huang, and Q. W. Qin, "Antiviral properties of hemocyanin isolated from shrimp Penaeus monodon," Antiviral Research, vol. 61, no. 2, pp. 93-99, 2004.

[6] Y. Zhang, S. Wang, A. Xu, J. Chen, B. Lin, and X. Peng, "Affinity proteomic approach for identification of an IgA-like protein in Litopenaeus vannamei and study on its agglutination characterization," Journal of Proteome Research, vol. 5, no. 4, pp. 815-821, 2006.

[7] Y. L. Zhang, F. Yan, Z. Hu et al., "Hemocyanin from shrimp Litopenaeus vannamei shows hemolytic activity," Fish and Shellfish Immunology, vol. 27, no. 2, pp. 330-335, 2009.

[8] N. Jiang, N. S. Tan, B. Ho, and J. L. Ding, "Respiratory proteingenerated reactive oxygen species as an antimicrobial strategy," Nature Immunology, vol. 8, no. 10, pp. 1114-1122, 2007.

[9] J. Markl, "Evolution and function of structurally diverse subunits in the respiratory protein hemocyanin from arthropods," Biological Bulletin, vol. 171, no. 1, pp. 90-115, 1986.

[10] R. J. Paul and R. Pirow, "The physiological significance of respiratory proteins in invertebrates," Zoology, vol. 100, no. 4, pp. 298-306, 1998.

[11] E. Jaenicke, R. Föll, and H. Decker, "Spider hemocyanin binds ecdysone and 20-OH-ecdysone," Journal of Biological Chemistry, vol. 274, no. 48, pp. 34267-34271, 1999.

[12] K. Adachi, K. Wakamatsu, S. Ito et al., "An oxygen transporter hemocyanin can act on the late pathway of melanin synthesis," Pigment Cell Research, vol. 18, no. 3, pp. 214-219, 2005.

[13] F. Yan, Y. L. Zhang, R. P. Jiang et al., "Identification and agglutination properties of hemocyanin from the mud crab (Scylla serrata)," Fish \& Shellfish Immunology, vol. 30, no. 1, pp. 354-360, 2011.

[14] D. Sellos, S. Lemoine, and A. Van Wormhoudt, "Molecular cloning of hemocyanin cDNA from Penaeus vannamei (Crustacea, Decapoda): Structure, evolution and physiological aspects," FEBS Letters, vol. 407, no. 2, pp. 153-158, 1997.

[15] S. M. Sun, L. Q. Chen, J. G. Qin et al., "Molecular cloning, characterization and mRNA expression of copper-binding protein hemocyanin subunit in Chinese mitten crab, Eriocheir sinensis," Fish \& Shellfish Immunology, vol. 33, no. 5, pp. 1222-1228, 2012.
[16] D.-L. Wang, T. Sun, D. Zuo, L.-M. Wang, Q. Wang, and Y.L. Zhao, "Cloning and tissue expression of hemocyanin gene in Cherax quadricarinatus during white spot syndrome virus infection," Aquaculture, vol. 410-411, pp. 216-224, 2013.

[17] K. Kusche and T. Burmester, "Molecular cloning and evolution of lobster hemocyanin," Biochemical and Biophysical Research Communications, vol. 282, no. 4, pp. 887-892, 2001.

[18] J. C. Marxen, C. Pick, M. Kwiatkowski, and T. Burmester, "Molecular characterization and evolution of haemocyanin from the two freshwater shrimps Caridina multidentata (Stimpson, 1860) and Atyopsis moluccensis (De Haan, 1849)," Journal of Comparative Physiology B: Biochemical, Systemic, and Environmental Physiology, vol. 183, no. 5, pp. 613-624, 2013.

[19] S. P. Lall, “The minerals," in Fish Nutrition, J. E. Halver and R. W. Hardy, Eds., pp. 259-308, Academic Press, New York, NY, USA, 2002.

[20] T. Watanabe, V. Kiron, and S. Satoh, "Trace minerals in fish nutrition," Aquaculture, vol. 151, no. 1-4, pp. 185-207, 1997.

[21] M.-H. Lee and S.-Y. Shiau, "Dietary copper requirement of juvenile grass shrimp, Penaeus monodon, and effects on nonspecific immune responses," Fish \& Shellfish Immunology, vol. 13, no. 4, pp. 259-270, 2002.

[22] S. M. Sun, J. G. Qin, N. Yu, X. Ge, H. Jiang, and L. Chen, "Effect of dietary copper on the growth performance, nonspecific immunity and resistance to Aeromonas hydrophila of juvenile Chinese mitten crab, Eriocheir sinensis," Fish \& Shellfish Immunology, vol. 34, no. 5, pp. 1195-1201, 2013.

[23] Y. Yang, S. Q. Xie, W. Lei, X. Zhu, and Y. Yang, "Effect of replacement of fish meal by meat and bone meal and poultry by-product meal in diets on the growth and immune response of Macrobrachium nipponense," Fish and Shellfish Immunology, vol. 17, no. 2, pp. 105-114, 2004.

[24] X. Y. Pan, J. Y. Shen, J. Y. Li et al., "Identification and biological characteristics of the pathogen causing Macrobrachium nipponense soft-shell syndrome," Microbiology, vol. 36, no. 10, pp. 1571-1576, 2009.

[25] J. Y. Shen, D. Qian, W. Liu et al., "Studies on the pathogens of bacterial diseases of Macrobrachium nipponense," Journal of Zhejiang Ocean University (Nature Science), vol. 19, no. 3, pp. 222-224, 2000.

[26] W. F. Wang, X. C. Xia, F. Liu, X. Chen, H. Yang, and Q. Ning, "Cloning and characterization of the hemocyanin gene of prawn Macrobrachium nipponense," Turkish Journal of Biochemistry, vol. 37, no. 4, pp. 348-355, 2012.

[27] D. Zhao, S. Song, Q. Wang, X. Zhang, S. Hu, and L. Chen, "Discovery of immune-related genes in Chinese mitten crab (Eriocheir sinensis) by expressed sequence tag analysis of haemocytes," Aquaculture, vol. 287, no. 3-4, pp. 297-303, 2009.

[28] E. Li, N. Yu, L. Chen, C. Zeng, L. Liu, and J. G. Qin, "Dietary vitamin $\mathrm{B}_{6}$ requirement of the pacific white shrimp, Litopenaeus vannamei, at low salinity," Journal of the World Aquaculture Society, vol. 41, no. 5, pp. 756-763, 2010.

[29] Association of Official Analytical Chemists (AOAC), Official Methods of Analysis, Association of Official Analytical Chemists (AOAC), Arlington, Va, USA, 13th edition, 1980.

[30] P. Wu, D. Qi, L. Chen et al., "Gene discovery from an ovary cDNA library of oriental river prawn Macrobrachium nipponense by ESTs annotation," Comparative Biochemistry and Physiology-Part D: Genomics and Proteomics, vol. 4, no. 2, pp. 111-120, 2009. 
[31] K. J. Livak and T. D. Schmittgen, "Analysis of relative gene expression data using real-time quantitative PCR and the $2^{-\Delta \Delta C T}$ method," Methods, vol. 25, no. 4, pp. 402-408, 2001.

[32] T. N. Petersen, S. Brunak, G. von Heijne, and H. Nielsen, "SignalP 4.0: discriminating signal peptides from transmembrane regions," Nature Methods, vol. 8, no. 10, pp. 785-786, 2011.

[33] S. A. Lehnert and S. E. Johnson, "Expression of hemocyanin and digestive enzyme messenger RNAs in the hepatopancreas of the black tiger shrimp Penaeus monodon," Comparative Biochemistry and Physiology-B Biochemistry and Molecular Biology, vol. 133, no. 2, pp. 163-171, 2002.

[34] W. Voll and R. Voit, "Characterization of the gene encoding the hemocyanin subunit e from the tarantula Eurypelma californicum," Proceedings of the National Academy of Sciences of the United States of America, vol. 87, no. 14, pp. 5312-5316, 1990.

[35] G. von Heijne, "How signal sequences maintain cleavage specificity," Journal of Molecular Biology, vol. 173, no. 2, pp. 243-251, 1984.

[36] J. Sun, B. J. Wang, Z. J. Sun et al., "cDNA cloning and sequence analysis of hemocyanin in Fenneropenaeus chinensis," Progress in Fisheries Science, vol. 31, no. 1, pp. 80-89, 2010.

[37] J. Rainer and M. Brouwer, "Hemocyanin synthesis in the blue crab Callinectes sapidus," Comparative Biochemistry and Physiology Part B: Comparative Biochemistry, vol. 104, no. 1, pp. 69-73, 1993.

[38] Y. L. Zhang, Z. J. Lin, Z. J. Li et al., "Identification of the main proteins binding with pathogen directly in Litopenaeus vannamei serum," Journal of Fisheries of China (China), vol. 32, no. 1, pp. 105-110, 2008.

[39] X. Zhao, L. Guo, Y. Zhang et al., "SNPs of hemocyanin Cterminal fragment in shrimp Litopenaeus vannamei," FEBS Letters, vol. 586, no. 4, pp. 403-410, 2012.

[40] M. Longshaw, "Diseases of crayfish: a review," Journal of Invertebrate Pathology, vol. 106, no. 1, pp. 54-70, 2011.

[41] G. Vivekanandhan, A. A. M. Hatha, and P. Lakshmanaperumalsamy, "Prevalence of Aeromonas hydrophila in fish and prawns from the seafood market of Coimbatore, South India," Food Microbiology, vol. 22, no. 1, pp. 133-137, 2005.

[42] J. P. Truchot, "Respiratory function of arthropod hemocyanins," in Blood and Tissue Oxygen Carriers, C. P. Mangum, Ed., vol. 13 of Advances in Comparative and Environmental Physiology, pp. 377-410, Springer, Berlin, Germany, 1st edition, 1992.

[43] A. Bellelli, B. Giardina, M. Corda et al., "Sexual and seasonal variability of lobster hemocyanin," Comparative Biochemistry and Physiology-Part A: Physiology, vol. 91, no. 3, pp. 445-449, 1988. 

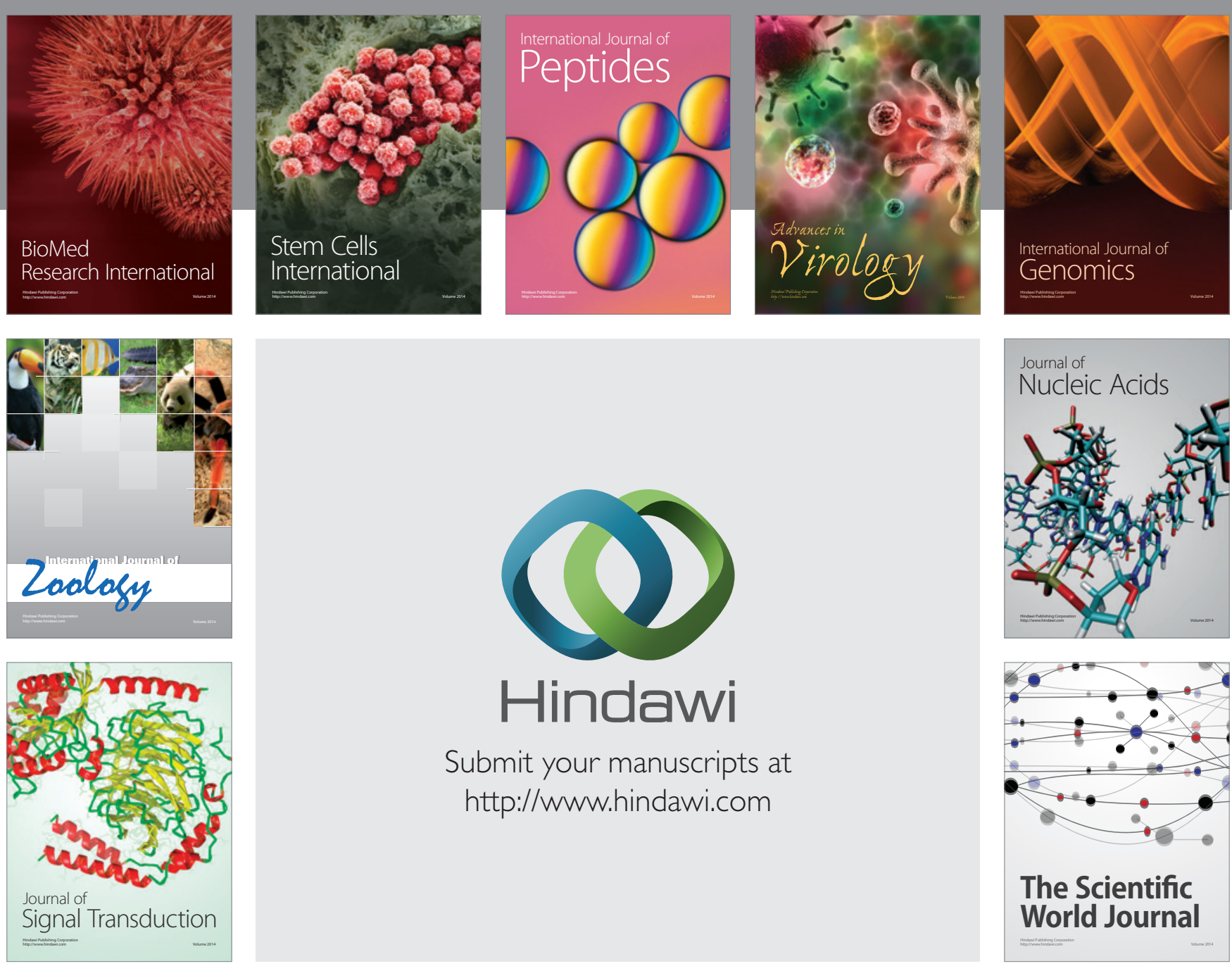

Submit your manuscripts at

http://www.hindawi.com
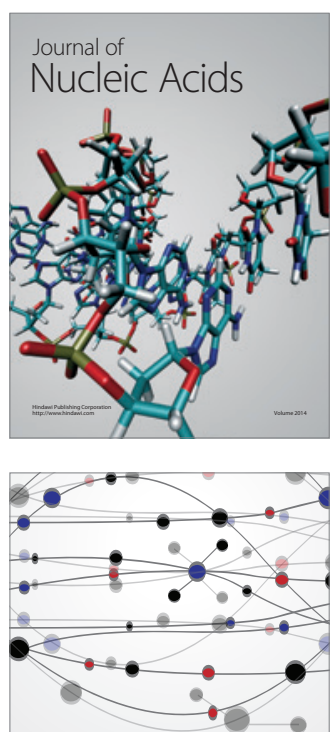

The Scientific World Journal
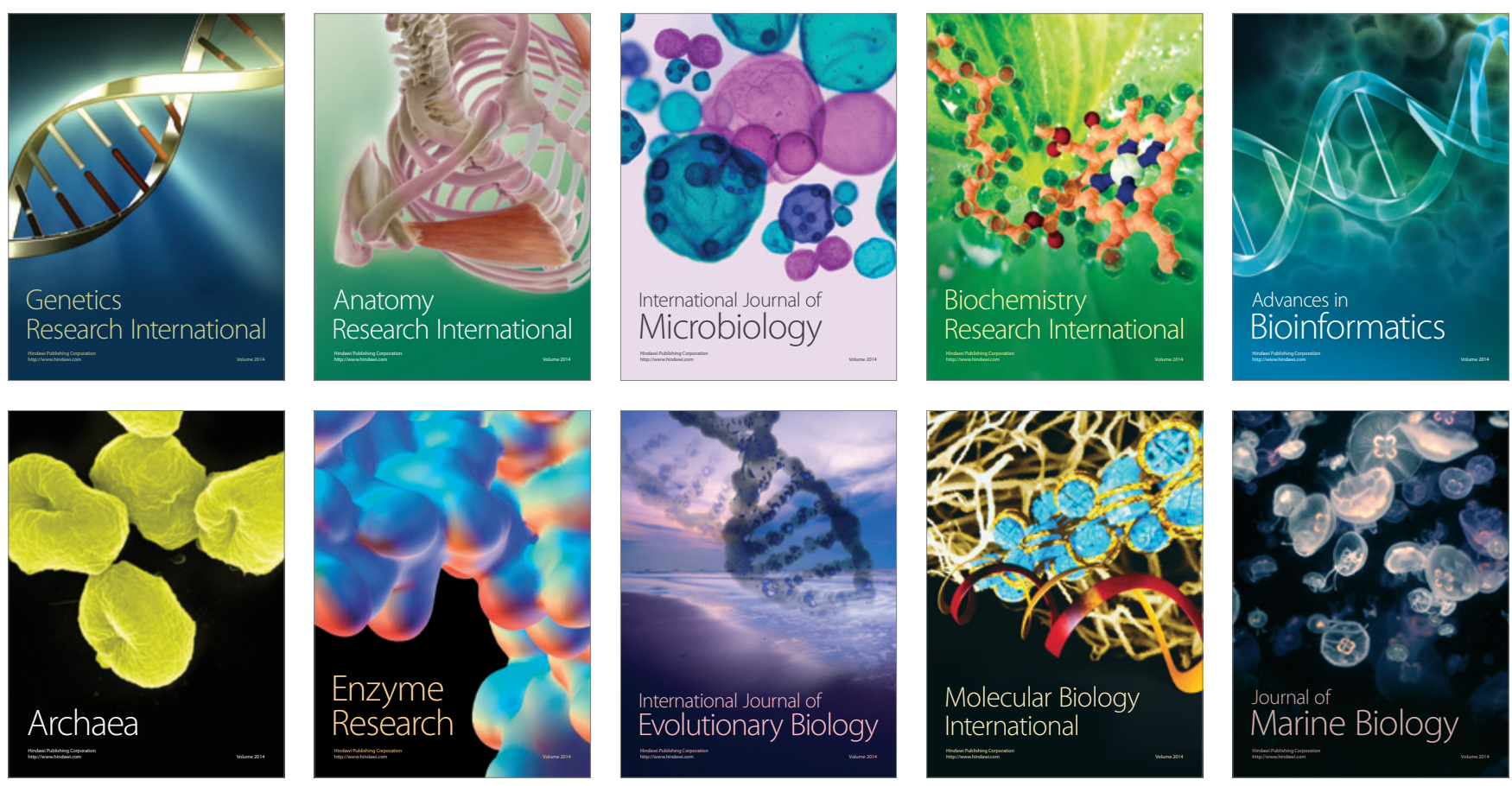